\title{
BENDE LÍVIA: TEMETKEZÉSI SZOKÁSOK A KÖRÖS-TISZA-MAROS KÖZÉN AZ AVAR KOR MÁSODIK FELÉBEN
}

\section{SZÜCSI FrigYes}

Magyar Régészet 9. évf. (2020), 1. szám, pp. 61-64. doi: https://doi.org/10.36245/mr.2020.1.10

\begin{abstract}
A fiatalon elhunyt Bende Livia 2006-ban védett doktori disszertációjából megjelentetett kötet az avar kor második felére jellemzö temetkezési szokásokat dolgozza fel egy jól körülhatárolható földrajzi régióban, a Körös-Tisza-Maros közén. Manapság mármár közhely megemlíteni, hogy milyen kiemelkedöen fontos egy adott régészeti korszak teljes körü regionális elemzése, a Kárpát-medence jelentös területei kapcsán azonban az avar kori kutatás még adós ezzel. Bende Livia a regionális kutatások hagyományait követi, munkája mégis több szempontból úttörö és vitathatatlanul hiánypótló. Ez az, ami meggyözöen alátámasztja az értekezés közreadását a doktori védés óta eltelt több mint egy évtized távlatában.
\end{abstract}

A temetkezési szokások részletes, nagy gyüjtésen alapuló regionális vizsgálata korábban rendszerint egy-egy rítuselem elemzésére korlátozódott, ahogy arra a bevezetésben a szerző is felhívta a figyelmet (ezzel kapcsolatban Tomka Péter munkásságát emelte ki). A kötet egyrészt az avar kor kutatásának hiátusaira mutat rá; másrészt a szerző munkájának úttörő jelentőségét támasztja alá az a tény, hogy a vizsgált területet - hasonló, teljes körü elemzések hiányában - nem állt módjában más régiókkal összevetni.

Bende Lívia doktori disszertációját - és az abból megjelent könyvet - az avar kori régiókat vizsgáló kutatók sora tekinti mintaadó alapműnek és követendő, továbbfejleszthető példának (BALOGH, 2016, 8; SzÜCSI, 2019a). Ugyanis lassan, de biztosan halad a kutatás abba az irányba, hogy az egykori Avar Kaganátus teljes területéről rendelkezésünkre álljanak a rítuselemek és a leletanyag egészére kiterjedő regionális feldolgozások. Ily módon szinte néprajzi tájak rajzolódnak ki a szemünk előtt az avar korban, de a regionális módszer lehetőségei még ennél is jóval messzebbre mutatnak. Az egyes régiókban a tárgytípusok használatának és a divatjelenségeknek pontosabb időrendje állítható fel, továbbá - részben a pontos időrendre, részben a helyi „,néprajzi” jellegzetességekre támaszkodva - szerencsés esetben belső és külső migráció nyomai ragadhatók meg. A szerzőnek ezzel a módszerrel sikerült elkülönítenie a helyi, kora avar gyökerekkel rendelkező népességet - amelynek a 7. század második felében az új temetők nyitása alapján elmozdult a településterülete -, valamint a Tisza mentére újonnan betelepülö, közép avar kori tárgyi kultúrával jellemezhető közösségeket. A közép avar anyagi műveltség ténye az utóbbi csoportok avar szállásterületen belüli származása mellett szól. 
Szücsi Frigyes • Bende Livia: Temetkezési szokások a Körös-Tisza-Maros közén az avar kor második felében

Már a címből kiderül, hogy a kutató két korszakot különített el az avar korban a szokásos hármas felosztás (kora, közép és késő avar kor) helyett. A két periódus elkülönítése vitathatatlanul indokolt a KörösTisza-Maros köze vonatkozásában, hiszen - ahogy arra Bende Lívia rámutat - ott nem találhatók az egész avar koron át használt temetők. A kora avar kori temetők használata a 7. század második felében lezárult, és ugyanabban az időszakban, de - részben a korábbitól eltérő területeken - nagyobb számban új temetőket nyitottak. A 7. század közepe táján az avar szállásterületen meginduló változások pontos időrendjének megragadása a mai napig nehézséget jelent a kutatás számára. Emiatt nem meglepő, hogy a szerző sem tudta megállapítani, hogy ,, a kora avar kori temetök használatával pontosan mikor és milyen okokra viszszavezethetöen hagytak fel, és a 7. század második felében mikor indult meg a nagy késői temetök betelepítése”. Ez a tény önmagában - a kora avar kori temetők felhagyása és új temetők nyitása - rámutat az avar kori Kárpát-medence nagyobb területi egységeinek az eltérő fejlődésére. A Dunától nyugatra ugyanis igen gyakori a nagyobb temetők használatának kontinuitása az egész avar koron átívelve (elég itt a zamárdi és a csákberényi temetőt, valamint a recenzens által vizsgált mezőföldi régióban általánosnak mondható kora avar kori temetök folyamatos használatát kiemelni).

A bevezetést azoknak a síroknak a katalógusa követi, amelyre az elemzés támaszkodik. A kutatás számára a katalógus használhatóságát, hasznosságát növelné, ha képmellékletek is társulnának hozzá, mert ebben a formában csak az elemzésben szereplő adatok ellenőrzésére szolgálhat. A katalógusban szereplő sírleírásokat képmellékletekkel és lehetőség szerint önálló temetőelemzéssel kiegészítve érdemesebb lett volna külön kötet(ek)et összeállítani.

A tájolási adatok megadásakor a legtöbb publikációban elmarad annak az egyértelmü megjelölése, hogy az adott tájolási tartományba - a ma legelterjedtebb 360 fokos rendszer szerint - mely fokok tartoznak. Dicséretes, hogy Bende Lívia ennek a tisztázásával kezdte a sírok tájolásából levonható következtetéseknek szánt 4. fejezetet. A vizsgált területen a kora avar korban jellemző ÉK-DNy-i, illetve K-Ny-i tájolás helyett a késő avar korban az ÉNy-DK-i tájolási irány lett a meghatározó. Ebből a szempontból tehát nincs kontinuitás a kora és a késő avar kor között. A szerző a szisztematikusan összegyüjtött adatokra támaszkodva megállapította, hogy a temetőkbe temetkező közösségek között pusztán a sírok tájolása alapján nem különíthetők el a különböző hagyományokkal bíró csoportok.

Mind a hitvilágra, mind az egykori közösség társadalmi rétegzödésére vonatkozóan elengedhetetlenül fontos információk szerezhetők a sírformák, a sírgödrök méretének és kialakításának elemzéséből, amelyre a kötet 5. fejezete épül.

A padkás sírok elemzése során (5.2. alfejezet) a 231. lábjegyzetben szerepel annak a jelentős körülménynek a megemlítése, hogy gyakran nem dönthetö el, vajon a ,sírgödör eredendöen padkás volt-e, vagy formája a sírbontás során alakult így". Ennek tudatában is egyetérthetünk azzal a kijelentéssel, hogy a „, bántóan kevésnek” tünő esetszám ellenére ,, e sírforma szerepe mégsem lehetett jelentéktelen”, mert „, a 10 lelőhely között, ahol a jelenség elöfordul, valamennyi nagy temetöt, temetörészletet megtaláljuk”.

A sírépítményekről szóló (5.3.) alfejezetben hivatkozott 2. ábra sajnos kimaradt a kötetből, holott jelentősen segítette volna a szerző által körülírt sírépítmény-típusok értelmezését. A cölöpös sírok alkalmazásának regionálisan eltérő, fontos különbségeire számos adat utal, amint az Bende Lívia figyelmét is felkeltette. A vizsgált területen - szemben például a dunántúli régióval (SzücsI, 2019b, 112) - ez ritka szokásnak tünik, hiszen a vizsgált 3277 sír közül mindössze 21 esetben, tehát elenyésző számban regisztráltak cölöplyukszerü kiugrásokat a sír falsíkjain. Bendének szembetủnt, hogy a Körös-Tisza-Maros közén ,,ezekben a sírokban nem jellemzö a nagytestü áldozatiállat-melléklet”, eltérően például számos dunántúli és délfelvidéki esettől (TRugLY, 2008, 82-83; SzÜCSI, 2015, 15-64). Időrendi különbségek is előtűnnek a Kárpát-medence egyes régiói között, hiszen úgy tünik, hogy ez a sírforma a 8. században jellemzö az elemzett területen, azaz később jelent meg itt, mint a kora avar kori eseteket is felmutató Dunántúlon (SzÜCSI, 2019a, 31) vagy a Duna-Tisza közén, ahol a 7. század második negyedétől számolhatunk vele (BALOGH, 2016, 45).

Kiemelten nagy figyelmet fordított Bende Lívia a fülkesírokra (5.4. alfejezet), mert az avar kor második felében a Körös-Tisza-Maros köze a fülkesíros temetkezés törzsterülete volt. Férfiakat, nőket és ritkábban gyermekeket is temettek ilyen módon. Fontos megállapítás, hogy a sírok kialakítása számos formai válto- 
Szücsi Frigyes • Bende Livia: Temetkezési szokások a Körös-Tisza-Maros közén az avar kor második felében

zatot mutat, de ezek nem térnek el a kora avar kori formáktól. A szerző a temetkezési rítus terén is a kapcsolatokat hangsúlyozta a kora avar kori, illetve az avar kor második felének idősebb (lényegében közép avar kori) fülkesírjai között. Ezzel összefüggésben kiemeli a juhkeresztcsont és -csigolyák ételmellékletként adását; az edénymellékleteket a fülke szájában vagy az eltemetett ember koponyája mellett; valamint a részlegesen elhantolt áldozati állatok jelenlétét - igaz, a kora avar korhoz képest jelentősen kisebb menynyiségben. Felfigyelt arra, hogy a temetőkben a késői jellegü fülkesírok egy sorban, illetve sávban való elhelyezkedésének a szabályszerűsége kronológiai jelentőséggel bír. A kései fülkesírok idősebb horizontja a 7. század közepétöl a 8. század elejéig regisztrálható, majd több generációs szünet után, az avar kor végén jelent meg ismét ez a temetkezési szokás. A temetőket használó népesség kontinuitása ellenére máig kérdéses, hogy miért hagytak fel hosszú évtizedekre a fülkesírok létesítésével, továbbá mi lehet a magyarázata a szokás reneszánszának a 8. század végén - 9. század elején, még ha oly elenyésző is az esetszám.

A 6. fejezet a halottak sírba helyezésének módjáról szól. A koporsóhasználat a vizsgált régióban is általánosnak tekinthető az avar korban. A szerző azokat az eseteket tekintette különlegesnek, amikor a koporsót valamilyen módon oltalmazták a visszatöltött földdel való érintkezéstől. Erre szolgáltak az alábbi sírformák: fülke-, padkás és cölöpös sír. Ilyen értelemben a Körös-Tisza-Maros közén a késő avar korban a cölöpszerkezetes és a padkás sírok vették át a fülkesírok helyét. A rendellenes temetkezések (zsugorítva eltemetett vagy hason fekvő halott) és a kettős, illetve többes temetkezések az avar kori temetőkben megszokott csekély számban fordultak elö.

A viseleti elemek és a tárgyi mellékletek temetkezési rítusban betöltött szerepének vizsgálatára tér ki a 7 . és a 8. fejezet. Az elemzés azonban nem terjedt ki a sírokból előkerült tárgyak osztályozására és időrendjére, ami érezhetően behatárolta az elérhető eredményeket. Ennek ellenére az egyes tárgytípusoknak szentelt egy-két mondat - legfeljebb egy bekezdés - is számos fontos adatot és megfigyelést tartalmaz. Figyelemre méltó észrevétel például, hogy míg a kora avar kori Tiszántúlon az edények döntő többsége a koponya mellől került elö, addig a vizsgált korszakban - az avar kor második felében - az idő előrehaladtával egyre ritkábban helyezték a fej mellé a kerámiaedényeket (a későbbi időszakban ezek helye a lábak, elsősorban a lábfejek környéke). A vizsgált térben és időben jellemző a fegyvermellékletek csekély száma, melyek ráadásul zömmel a 7 . század második és a 8 . század első felében megásott sírokba kerültek. Bende részletesen vizsgálta a lószerszámos temetkezéseket, mert ez a szokás - noha szórványosan szinte Avaria teljes területén előfordult - a legnagyobb számban éppen a Körös-Tisza-Maros közéről, illetve közeléből ismert. Bende Lívia definíciója alapján ,, a szokás - amint azt az elnevezése is mutatja - a lószerszámnak vagy elemeinek a temetés során való sírba helyezését jelenti, anélkül, hogy az elhunyt mellé akár egész, akár részleges lovat mellékeltek volna" (lásd 8.5. fejezet). A vizsgált területen a lószerszámos temetkezések 90\%-ában férfiak - minden korcsoport, de zömében az idősebbek - érintettek. A lószerszámos temetkezés gyakran kombinálva jelentkezik a fülkesíros temetkezési szokással.

Az összefoglalás előtti utolsó, 9. fejezetben kapott helyet az állatokkal kapcsolatos mellékletek temetkezési rítusban betöltött szerepének az elemzése. A szerző elkülönítette egymástól a sírba helyezett áldozati állatokat és az ételmellékleteket, melyeket külön alfejezetekben vett górcső alá. Nehézséget jelentett, hogy a vizsgált terület temetői közül egynek sem jelent meg nyomtatásban a részletes archaeozoológiai vizsgálata. A kutató a rendelkezésre álló eredmények példás összegyüjtésével azonban figyelemre méltó eredményekre jutott. A Körös-Tisza-Maros közén a temetkezési rítus meghatározó részének bizonyult az áldozati állatok sírba helyezése. A kora avar korhoz képest új elem az egész állatok (marha, juh) sírba helyezése, a részleges lóáldozat eltünése, valamint a részleges marha- és juháldozat esetén a lábak csonkolása helyett a lefejtésük. A szarvasmarha és a juh jelenléte a nagyállattartó életmód bizonyítéka, de ételmellékletként egyre nagyobb szerephez jutottak a szárnyasfélék.

Örvendetes, hogy a kötet függelékében megjelentek a pitvaros-víztározói temető radiokarbon keltezésének, embertani és archaeozoológiai vizsgálatának eredményeit bemutató írások Siklósi Zsuzsanna, Lőrinczy Gábor, Molnár Erika és Vörös István tollából. A régészeti kronológia alapján a temető felhagyása a 835-850 körüli időszakra tehető, ezzel szemben tíz - időrendi szempontból releváns - sír radiokarbon keltezése alapján a temető használata legkésőbb már a 8. század végén befejeződött. További - várhatóan 
a közeljövőben közlésre kerülö - radiokarbon eredmények arra utalnak, hogy ez a probléma túlmutat a pitvarosi temetőn, és az ellentmondás feloldása a jövőbeli kutatástól várható.

A népvándorlás kor kutatói számára rendkívül hasznos az imént ismertetett vaskos kötet, mely gigászi munka tanúbizonysága. Jelentőségét és az avar kor kutatásában való megkerülhetetlenségét mutatja, hogy a könyv megjelenését követően 1-2 évvel már hivatkoznak rá a friss publikációk. Méltó emléket állít ez a fájdalmasan fiatalon elhunyt kutatónak.

\section{FELHASZNÁLT IRODALOM}

Balogh, Cs. (2016). Régészeti adatok a Duna-Tisza közi avarok történetéhez. Studia ad Archaeologiam Pazmaniensia 6. Budapest: Archaeolingua.

Szücsi, F. (2015). Avar kori temetök Nagyvenyimről. A Munkácsy utca - Füzfa utcai, a határvölgypusztai és a jármüjavítói temetőrészletek. Alba Regia 43, 15-64.

Szücsi, F. (2019a). Temetkezési szokások az avar kori Mezőföldön és az 5-10. századi térhasználati és kontinuitási kérdések (Doktori disszertáció). Pázmány Péter Katolikus Egyetem Bölcsészet- és Társadalomtudományi Kar, Történelemtudományi Doktori Iskola, Régészeti Mühely, Budapest.

Szücsi, F. (2019b). „Az ismeretlen ismerős”. Új eredmények a csákberény-orondpusztai avar kori temető kutatásából. In Sudár B. \& Türk A. (szerk.), Hadak útján. A népvándorláskor fiatal kutatóinak XXIX. konferenciája. Budapest, 2019. november 15-16. Absztraktkötet (pp. 112). Studia ad Archaeologiam Pazmaniensia 14. - Magyar Östörténeti Témacsoport Kiadványok 7. Budapest: Bölcsészettudományi Kutatóközpont Magyar Östörténeti Témacsoport - Martin Opitz Kiadó - PPKE BTK Régészettudományi Intézet.

Trugly, S. (2008). A Komárom-hajógyári avar temető és telep. Budapest: Martin Opitz Kiadó. 